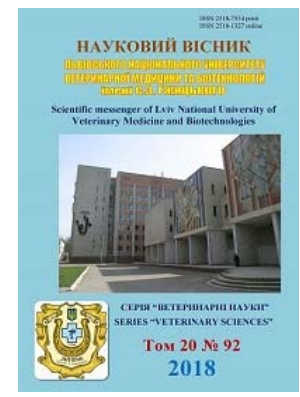

\author{
Науковий вісник Дьвівського національного університету \\ ветеринарної медицини та біотехнологій імені С.3. Гжицького
}

\author{
Scientific Messenger of Lviv National University \\ of Veterinary Medicine and Biotechnologies
}

ISSN 2518-7554 print

doi: $10.32718 /$ nvlvet9244

ISSN 2518-1327 online

http://nvlvet.com.ua

UDC 619:612.121:616.006:636.7+636.8

\title{
Glutathione peroxidase of blood of dogs and cats with mammary tumors
}

\author{
O.M. Fedets, I.M. Kurlyak, O.I. Zayats
}

Stepan Gzhytskyi National University of Veterinary Medicine and Biotechnologies Lviv, Ukraine

Article info

Received 08.11.2018

Received in revised form 10.12 .2018

Accepted 11.12.2018

Stepan Gzhytskyi National University of Veterinary Medicine and Biotechnologies Lviv,

Pekarska Str., 50, Lviv, 79010, Ukraine.

Tel.: +38-067-411-14-46

E-mail:fedets@lvet.edu.ua
Fedets, O.M., Kurlyak, I.M., \& Zayats, O.I. (2018). Glutathione peroxidase of blood of dogs and cats with mammary tumors. Scientific Messenger of Lviv National University of Veterinary Medicine and Biotechnologies, 20(92), 213-217. doi: 10.32718/nvlvet9244

For timely diagnostics and successful treatment of mammary tumors in human and animals a necessary search of compounds that can be the biomarkers of this disease is needed. The aim of our work was to measure the activity of glutathione peroxidase (GPx) in blood plasma and erythrocytes of dogs and cats with mammary tumors and healthy animals for establishment of intercommunication between enzyme's activity and tumors. For researches took away blood at three groups of animals: 1) four healthy females of dogs (Canis familiaris) - the German Shepherd dogs by age 3, 6, 7 and 7; 2) four females of dogs with mammary tumors - the Russian Spaniel dog by age 8, Boxer dog by age 9 and the German Shepherd crossbred dogs by age 11 and 12;3) four females of cats (Felis catus) with mammary tumors - crossbred cats by age 6, 8 and 10 and the Persian crossbred cat by age 13. Activity of GPx was determined by decrease of reduced glutathione in a presence of hydrogen peroxide for time unit with a count on the gramme of protein in blood plasma, or haemoglobin in erythrocytes. In the sick dogs' erythrocytes the activity of GPx presents $30.45 \pm 3.08 \mathrm{mmol} \mathrm{GSH} / \mathrm{min} \times \mathrm{g}$ haemoglobin and it is more than for the healthy animals of $27.84 \pm 5.24$ mmol GSH/min $\times g$ haemoglobin, these differences aren't statistically reliable however. This index is the highest for the sick German Shepherd crossbred dog aged 11 and presents $38.5 \mathrm{mmol} \mathrm{GSH} / \mathrm{min} \times \mathrm{g}$ haemoglobin. In sick dogs' activity of GPx in blood plasma is $7.45 \pm 1.60 \mathrm{mmol} \mathrm{GSH} / \mathrm{min} \times \mathrm{g}$ protein and it is statistically reliable less than the healthy animals of $12.77 \pm 1.18 \mathrm{mmol} G S H / \mathrm{min} \times g$ protein. This index is the lowest for the the 12 years old sick German Shepherd crossbred dog and it is $3.41 \mathrm{mmol} \mathrm{GSH/min} \times \mathrm{g}$ protein. In sick cats activity of GPx in erythrocytes is $41.57 \pm 4.10 \mathrm{mmol} G S H / \mathrm{min} \times \mathrm{g}$ haemoglobin, and the greatest it is in the sick crossbred cat age $10-52.52 \mathrm{mmol}$ GSH/min $\times \mathrm{g}$ haemoglobin. The activity of the enzyme in blood plasma of sick cats is $11.58 \pm 1.99 \mathrm{mmol} \mathrm{GSH} / \mathrm{min} \times \mathrm{g}$ protein and this index is similar to the healthy dogs. Activity of GPx of the erythrocytes of dogs and blood plasma of cats with mammary tumors did not differ from healthy dogs. The activity of GPx of sick dogs only in blood plasma is less than in healthy ones. It can be the consequence of this "exhaustion" of the enzyme and its involving in the process of neutralizing of active forms of reactive oxygen species in those tissues of organism where oxidizing stress develops. Next to the study of expression on the future it is necessary to pay attention to the study of polymorphism of GPx.

Key words: glutathione, cancer, blood plasma, erythrocytes.

\section{Глутатіонпероксидаза крові собак і котів 3 пухлинами молочної залози}

\author{
О.М. Федець, I.М. Курляк, О.І. Заяць
}

Львівський національний університет ветеринарної медицини та біотехнологій імені С.3. Гжицького, м. Львів, Украӥна

Для своєчасної діагностики та успішного лікування новоутворень молочної залози у людини і тварин необхідний пошук сполук, які можуть бути біомаркерами цьього захворювання. Метою нашої роботи було визначити активність глутатіонпероксидази (GPx) в плазмі крові та еритрочитах собак $і$ котів з пухлинами молочної залози та здорових тварин для встановлення взаємозв'язку між активністю ензиму та новоутвореннями. Для досліджень відібрали кров у трьох груп тварин: 1) чотирьох здорових самок собак (Canis familiaris) - німецькі вівчарки віком 3, 6, 7 та 7 років; 2) чотирьох самок собак з пухлинами молочної залози російська спанієль віком 8 років, боксер віком 9 років та метиси німецької вівчарки віком 11 і 12 років; 3 ) чотирьох самок котів 
(Felis catus) з пухлинами молочної залози - метиси віком 6, 8 і 10 років та метис перської кішки віком 13 років. Активність GPх визначали за зменшенням відновленого глутатіону в присутності гідроген пероксиду за одиницю часу з перерахунком на грам білка в плазмі крові або гемоглобіну в еритроцитах. В еритроцитах хворих собак активність GPх становить $30,45 \pm 3,08$ мкмоль GSH/xв $\times 2$ гемоглобіну $і \epsilon$ більшою, ніж у здорових тварин $-27,84 \pm 5,24$ мкмоль GSH/хв $\times 2$ гемоглобіну, проте изі відмінності не $\epsilon$ статистично вірогідними. Найвичий ией показник у хворої метиса німецької вівчарки віком 11 років і становить 38,5 мкмоль GSH/xв $\times 2$ гемоглобіну. В плазмі крові хворих собак активність GPx становить 7,45 $\pm 1,60$ мкмоль GSH/хв $\times 2$ білка і є вірогідно меншою, ніж у здорових тварин - 12,77 $\pm 1,18$ мкмоль GSH/хв $\times_{2}$ білка. Найнижчий цей показник у хворої метиса німецької вівчарки віком 12 років і становить 3,41 мкмоль GSH/хв ×2 білка. У хворих котів активність GPхв еритрочитах становить 41,57 $\pm 4,10$

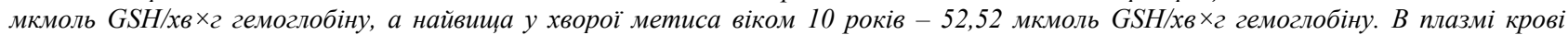
хворих котів активність ензиму 11,58 \pm 1,99 мкмоль GSH/хв ×2 білка, і цей показник подібний до показників у здорових собак. Лише в плазмі крові собак з пухлинами молочної залози активність GPх вірогідно менша, ніж у здорових. Це може бути наслідком “виснаження” иьього ензиму $i$ залучення його в прочес знешкодження активних форм кисню в тих тканинах організму, де розвивається окисний стрес. Поряд із вивченням експресї в майбутньому необхідно приділяти увагу вивченню поліморфізму GPх.

Ключові слова: глутатіон, рак, плазма крові, еритроцичти.

\section{Вступ}

Глутатіонпероксидаза (GPx, EC 1.11.1.9; глутатіон: гідроген пероксид оксидоредуктаза) каталізує глутатіон-залежне відновлення $\mathrm{H}_{2} \mathrm{O}_{2}$. Ензим є частиною глутатіонової системи.

У результаті клітинного метаболізму в організмі постійно утворюються вільні радикали, так звані активні форми кисню (АФК). Фізіологічно цей процес регулюють антиоксидантні ензими, до яких, зокрема, належить GPx. Тобто в організмі розвинені антиоксидантні системи захисту. Проте коли утворюється велика кількість вільних радикалів, ці ензими перевантажені, а вільні радикали індукують основні пошкодження клітин: це окисний стрес (Sagols and Priymenko, 2011). Вимірювання цього окисного стресу є ефективним фактором прогнозу і може допомогти в розробці нових терапевтичних препаратів для лікування раку (Wang et al., 2014).

Внутрішньоклітинне виробництво АФК пов'язане 3 пригніченням проліферації клітин. Генерація окисного стресу у відповідь на різні зовнішні подразники пов'язана 3 активацією факторів транскрипції та апоптозу. Окремі антиканцерогенні речовини інгібують утворення АФК та окисне пошкодження ДНК, пригнічуючи розвиток пухлин (Matés and Sánchez-Jiménez, 2000).

Тобто існує взаємоз'язок між розвитком пухлин і АФК, тому результати досліджень GPx, яка регулює утворення АФК, дозволять встановити взаємозв'язок цього ензиму з розвитком новоутворень.

Найбільше в цьому напрямку опубліковано результатів досліджень, які стосуються організму людини (Król et al., 2018), оскільки рак є однією з найбільших проблем людства. Науковці проводять пошук сполук, які мають діагностичне значення для встановлення стадії розвитку новоутворень та їх типу. Це необхідно для своєчасної діагностики та успішного лікування пухлин, тому дослідженню цього питання присвячено багато публікацій. Їхня екстраполяція на організм собаки чи кота повинна враховувати особливості обміну речовин у цих видів тварин. Найкраще одержати такі дані при дослідженні хворих тварин цих видів.

Необхідно також враховувати, що на активність GPx у крові тварин впливають різні фактори. Так, у крові анемічних собак активність ензиму значно ниж- ча, ніж у здорових тваринами (Kendall et al., 2017). Також показана залежність цього показника від форми анемії у собак (Gultekin and Voyvoda, 2017), але не виявлено статистично вірогідних відмінностей в активності GPx у собак з серцевою недостатністю (Verk et al., 2017). Активність ензиму в крові собак зростає в перші 60 хв після анестезії пропофолом чи севофолураном (Tomsič et al., 2018), та в перші 30 хв після анестезії комбінацією дексмедетомідину, мідазоламу, буторфанолу та атропіну (Feng et al., 2015), проте згодом цей показник приходить до норми. GPx може бути також використана як біомаркер для діагностики паразитарних захворювань собак. Зокрема встановлене зниження активності цього ензиму в крові тварин інфікованих Leishmania infantum (Lopes-Neto et al., 2016) та Babesia canis canis (Crnogaj et al., 2017). Тому кров для досліджень необхідно брати до анестезії та враховувати загальний стан організму тварин.

Метою роботи було визначити активність GPх в плазмі крові та еритроцитах собак і кішок з пухлинами молочної залози для встановлення взаємозв'язку між активністю ензиму та новоутвореннями.

\section{Матеріал і методи досліджень}

Для досліджень відібрали кров у трьох груп тварин: 1) чотирьох здорових самок собак (Canis familiar$i s)$ - німецькі вівчарки віком 3, 6, 7 та 7 років; 2) чотирьох самок собак з пухлинами молочної залози російська спанієль віком 8 років, боксер віком 9 років та метиси німецької вівчарки віком 11 і 12 років; 3) чотирьох самок котів (Felis catus) 3 пухлинами молочної залози - метиси віком 6, 8 і 10 років та метис перської кішки віком 13 років. Для отримання плазми (антикоагулянт $\mathrm{K}_{3} \mathrm{EDTA}$ ) кров центрифугували при 2-2,5 тис. об/хв. Еритроцити тричі промивали чотирикратним об'ємом $0,9 \%$ розчину $\mathrm{NaCl}$, після чого їх гемолізували, додаючи до 1 частини еритроцитів 9 частин $0,02 \%$ розчину сапоніну. Концентрацію білка плазми крові визначали з біуретовим реактивом (Gornall et al., 1949), концентрацію гемоглобіну еритроцитів визначали гемоглобінціанідним методом 3 використанням модифікованого реактиву Drabkin (Drabkin and Austin, 1935). У плазмі крові та гемолізаті еритроцитів визначали активність GPx за методом Pirie (1965): протягом 5 хв в реакційному середовищі, яке містило 0,5 ммоль глутатіону (GSH), 0,2 ммоль 
$\mathrm{H}_{2} \mathrm{O}_{2}, 1,5$ ммоль $\mathrm{NaN}_{3}$ (інгібітор каталази), 0,02 ммоль $\mathrm{Na}_{2}$ EDTA у 100 ммоль К-фосфатному буфері $(\mathrm{pH}=7,0)$; реакцію зупиняли додаванням метафосфатної кислоти до кінцевої концентрації 2,5\%. Концентрацію GSH визначали за методом (Beutler et al., 1963). Статистичний аналіз проводили з використанням t-тесту Ст'юдента (Р < 0,05 вважали статистично вірогідним).

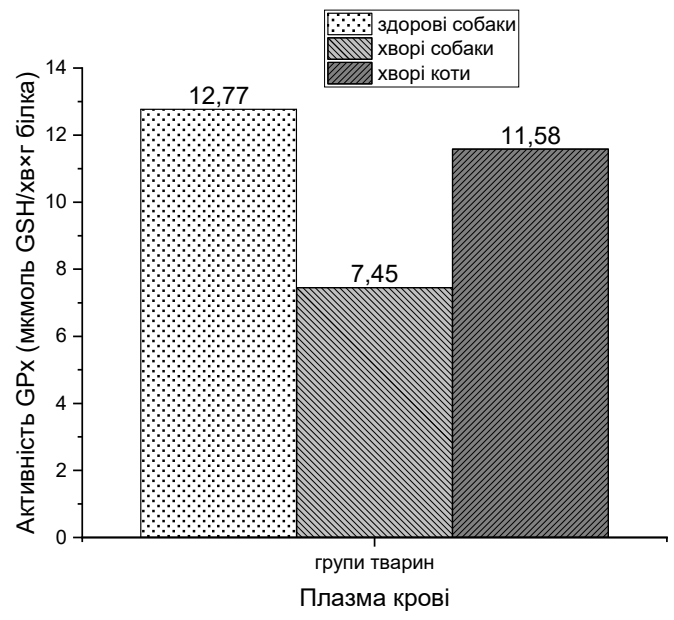

\section{Результати та їх обговорення}

В еритроцитах хворих собак активність GPх більша, ніж у здорових тварин, проте ці відмінності не $\epsilon$ статистично вірогідними (рис. 1). Найвищий цей показник у хворої метиса німецької вівчарки віком 11 років і становить 38,5 мкмоль GSH/хв $\times$ г гемоглобіну.

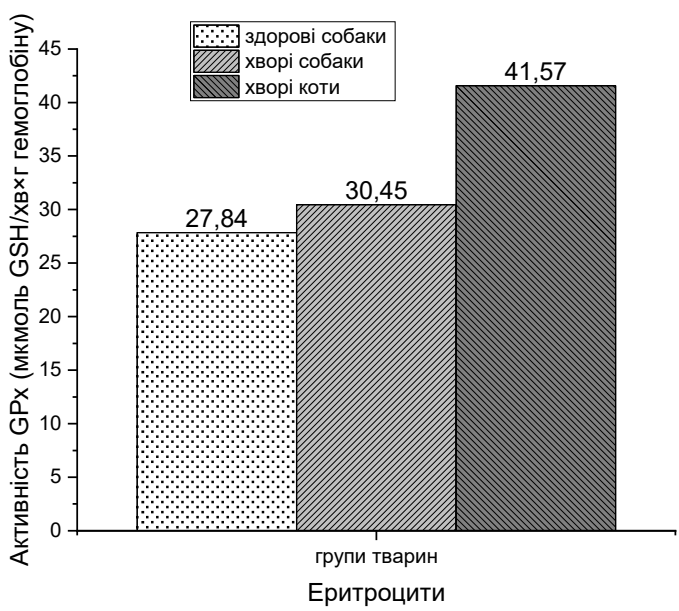

Рис. 1. Активність GPx у крові собак та котів

За даними (Plavec et al., 2008), середнє значення активності GPx не відрізнялось у здорових та хворих собак. Проте коли тварини були поділені на групи за типами новоутворень, то у тварин з остеосаркомою цей показник був вірогідно вищий, ніж у здорових тварин. У наших дослідженнях ми не робили такого аналізу через малу кількість зразків.

Згідно з результатами досліджень (Szczubiał et al., 2004) у собак 3 доброякісними новоутвореннями молочної залози активність ензиму в еритроцитах не відрізнялась від здорових тварин, проте була вірогідно вищою у тварин зі злоякісними новоутвореннями. Це може бути в результаті збільшення синтезу ензиму у відповідь на збільшення продукції АФК.

У плазмі крові хворих собак нами встановлено, що активність GPx вірогідно менша, ніж у здорових тварин (рис. 1). Найнижчий цей показник хворої метиса німецької вівчарки віком 12 років і становить 3,41 мкмоль GSH/хв $\times$ г білка, що майже в чотири рази менше, ніж у здорових тварин. Це може бути наслідком “виснаження" цього ензиму і залучення його у процес знешкодження активних форм кисню в тих тканинах організму, де розвивається окисний стрес, зокрема і в ураженій тканині молочної залози.

Згідно з (Pasquini et al., 2015) у собак з лімфомою в плазмі крові був значно підвищений рівень АФК та зменшений антиоксидантів. Це $\epsilon$ наслідком двох факторів. Перший - це зміна енергетичного обміну, що пов'язана 3 такими загальними симптомами, як анорексія, кахексія, нудота та блювота. Це перешкоджає регулярному надходженню таких речовин, як глюкоз, білки та вітаміни, що приводить до зміни харчового статусу та значного накопичення АФК. Другий - це хронічне виробництво АФК і можливе виснаження антиоксидантів, що може призвести до оксидативного стресу.

Проте в літературі є і протилежні дані. Так, в сироватці крові хворих жінок активність GPх була вищою, ніж у здорових. Не встановлена залежність між стадією раку молочної залози у них та активністю ензиму. Тобто, на думку авторів (Sadati Zarrini et al., 2016), окисний стрес на різних стадіях раку молочної залози є певною мірою подібний.

У собак $з$ лімфомою була підвищена активність GPx (Winter et al., 2009), проте ці результати є протилежними до отриманих (Vajdovich et al., 2005), згідно 3 якими ця активність, навпаки, зменшувалась, як видно і 3 наших результатів. Зниження активності можливе також і внаслідок хіміотерапії (Vajdovich et al., 2005).

За даними (Kumaraguruparan et al., 2005), у тканинах пухлин молочної залози собак була посилена пероксидація ліпідів порівняно з відповідними сусідніми неушкодженими тканинами. Це супроводжувалося значним підвищенням як ензиматичних, так i неензиматичних антиоксидантів. Підвищена регуляція антиоксидантів, які індуковані пероксидним окисненням ліпідів, забезпечує вибіркову перевагу росту пухлинних клітин над нормальними.

В уражених тканинах молочної залози жінок також встановлена посилена пероксидація ліпідів разом зі значним збільшенням як ензиматичних, так і неензиматичних антиоксидантів порівняно зі здоровими контролем. Тобто був посилений адаптативний механізм антиоксидантної системи (Wang et al., 2000).

У жінок з раком молочної залози нормальний окисно-відновний баланс змінюється і зростає роль ензи- 
матичних систем антиоксидантного захисту, що може відображати спробу попередження колонізації лімфатичних вузлів пухлинними клітинами. У цих жінок 3 макрометастазми в лімфатичних вузлах встановлено знижені рівень GSH та активність GPх. Рівень експреciï GPx запропонований як альтернативний маркер для жінок з раком молочної залози (Ramírez-Expósito et al., 2017). Проте у собак $з$ пухлинами молочної залози експресія GPx не корелювала з розвитком метастазів (Leonel et al., 2014).

Тобто зміни активності GPx у плазмі крові та еритроцитах відображають процеси, які відбуваються у тканині молочної залози, але залежать від розвитку патологічного процесу.

В таблиці також наведено дані активності GPx в плазмі крові та еритроцитах кішок з пухлинами молочної залози. Проте ми не порівнювали ці дані з показниками у здорових тварин цього виду.

В результаті досліджень, проведених (Todd et al., 2011), у кішок та собак не встановлено впливу споживання дієтичного селену різних форм на активність GPx у плазмі крові. Також не було відмінності в цій активності між видами (собака і кіт). Якщо ці відмінності незначні, то можна припустити, що у здорових котів активніст ь GPx у плазмі крові є близькою до показника у собак, а це не відрізняється від показника, отриманого нами у хворих котів (табл., рис.). В еритроцитах хворих котів активність ензиму значно більша, ніж у хворих і здорових собак, а найвищий цей показник у метиса кота віком 10 років і становить 52,52 мкмоль GSH/хв ×Г гемоглобіну.

Поліморфізм GPx може бути важливим фактором, який модифікує реакцію окисного стресу при раку молочної залози (Jablonska et al., 2015). Тому, поряд із дослідженням активності GPx, на майбутнє необхідно приділяти увагу вивченню їі поліморфізму.

\section{Висновки}

1. Активність GPx в плазмі крові собак з пухлинами молочної залози була вірогідно меншою, ніж у здорових, i цей показник може мати діагностичне значення.

2. Активність GPx в еритроцитах собак з пухлинами молочної залози не відрізнялась від здорових.

3. Активність GPx в плазмі крові котів з пухлинами молочної залози була, як у здорових собак, а в еритроцитах хворих котів більшою, ніж у здорових та хворих собак.

\section{Подяки}

Ця робота була фінансово підтримана Міністерством освіти і науки України (0118U003495).

\section{References}

Beutler, E., Duron, O., \& Kelly, B.M. (1963). Improved method for the determination of blood glutathione. Journal of Laboratory and Clinical Medicine, 61, 882-
888. PMID:13967893. https://www.ncbi.nlm.nih.gov/ pubmed/13967893.

Crnogaj, M., Cerón, J.J., Šmit, I., Kiš, I., Gotić, J., Brkljačić, M. et al. (2017). Relation of antioxidant status at admission and disease severity and outcome in dogs naturally infected with Babesia canis canis. BMC Vet. Res., 13(1), 114-122. doi:10.1186/s12917017-1020-9.

Drabkin, D.L., \& Austin, J.H., (1935). Spectrophotometric studies. II. Preparations from washed blood cells; nitric oxide hemoglobin and sulfhemoglobin. J. Biol. Chem., 112, 51-65. http://www.jbc.org/cgi/framedreprint/112/1/51.

Feng, X.J., Hu, X.Y, Zhang, S., Li, J.N., \& Fan, H.G. (2015). Effects of the dexmedetomidine, midazolam, butorphanol, and atropine combination on plasma oxidative status and cardiorespiratory parameters in raccoon dogs (Nyctereutes procyonoides). Veterinarni Medicina, 60(8), 450-455. doi: 10.17221/8420VETMED.

Gornall, A.G., Bardawill, C.J., \& David, M.M (1949). Determination of serum proteins by means of the biuret reaction. Journal of Biological Chemistry, 177(2), 751766. PMID:18110453. http://www.jbc.org/content/ 177/2/751.short.

Gultekin, M., \& Voyvoda, H. (2017). Evaluation of oxidative status in dogs with anemia. Med. Weter., 73(8), 496-499. doi: 10.21521/mw.5754.

Jablonska, E., Gromadzinska, J., Peplonska, B., Fendler, W., Reszka, E., Krol, M.B. et al. (2015). Lipid peroxidation and glutathione peroxidase activity relationship in breast cancer depends on functional polymorphism of GPX1. BMC Cancer., 15, 657-668. doi: 10.1186/s12885-015-1680-4.

Kendall, A., Woolcock, A., Brooks, A., \& Moore, G.E. (2017). Glutathione peroxidase activity, plasma total antioxidant capacity, and urinary F2- isoprostanes as markers of oxidative stress in anemic dogs. J Vet Intern Med., 31(6), 1700-1707. doi: 10.1111/jvim.14847.

Król, M.B., Galicki, M., Grešner, P., Wieczorek, E., Jabłońska, E., Reszka, E. et al. (2018). The ESR1 and GPX1 gene expression level in human malignant and non-malignant breast tissues. Acta Biochim Pol., 65(1), 51-57. doi: 10.18388/abp.2016_1425.

Kumaraguruparan, R., Balachandran, C., Manohar, B.M., \& Nagini, S. (2005). Altered oxidant-antioxidant profile in canine mammary tumours. Veterinary Research Communications, 29(4), 287-296. doi: 10.1023/B:VERC.0000048499.38049.4b.

Leonel, C., Gelaleti, G.B., Jardim, B.V., Moschetta, M.G., Regiani, V.R., Oliveira, J.G. \& Zuccari, D.A.P.C. (2014). Expression of glutathione, glutathione peroxidase and glutathione S-transferase pi in canine mammary tumors. BMC Veterinary Research, 10, 49-58. doi: 10.1186/1746-6148-10-49.

Lopes-Neto, B.E., Santos, G.J.L., Lima, A.L., Barbosa, M.C., Santos, T.E.J., \& Uchoa, D.C. et al. (2016). Catalase and glutathione peroxidase in dogs naturally infected by Leishman iainfantum. Acta Scientiae Vet- 
erinariae, 44, 1360-1365. http://www.ufrgs.br/actavet/ 44/PUB\%201360.pdf.

Matés, J.M., \& Sánchez-Jiménez, F.M. (2000). Role of reactive oxygen species in apoptosis: implications for cancer therapy. Int J Biochem Cell Biol., 32(2), 157170. PMID:10687951. https://www.ncbi.nlm.nih.gov/ pubmed/10687951.

Pasquini, A., Gavazza, A., Biagi, G., \& Lubas, G. (2015). Oxidative stress in lymphoma: Similarities and differences between dog and human. Comp Clin Pathol., 24, 69-73. doi: 10.1007/s00580-013-1856-8.

Pirie, A. (1965). Glutathione peroxidase in lens and a source of hydrogen peroxide in aqueous humour. Biochem J., 96(1), 244-253. PMID:14343138 https://www.ncbi.nlm.nih.gov/pubmed/14343138.

Plavec, T., Nemec-Steve, A., Butinar, J., Tozon, N., Prezelj, M., Kandel, B. \& Kessler, M. (2008). Antioxidant status in canine cancer patients. Acta Veterinaria Beograd, 58(2-3), 275-286. http://www.actaveterinaria. rs/volume/issue/8/41/331.

Ramírez-Expósito, M.J., Urbano-Polo, N., Dueñas, B., Navarro-Cecilia, J., Ramírez-Tortosa, C., MartínSalvago, M.D., \& Martínez-Martos, J.M. (2017). Redox status in the sentinel lymph node of women with breast cancer. Ups J Med Sci., 122(4), 207-216. doi: 10.1080/03009734.2017.1403522.

Sadati Zarrini, A., Moslemi, D., Parsian, H., Vessal, M., Mosapour, A., \& Shirkhani Kelagari, Z. (2016). The status of antioxidants, malondialdehyde and some trace elements in serum of patients with breast cancer. Caspian J. Intern. Med., 7(1), 31-36. PMID:26958330 https://www.ncbi.nlm.nih.gov/pubmed/26958330.

Sagols, E., \& Priymenko, N. (2011). Oxidative stress in dog with heart failure: the role of dietary fatty acids and antioxidants. Vet Med Int., 2011(6), 180206-180210. doi: 10.4061/2011/180206.

Szczubiał, M., Kankofer, M., Łopuszyński, W., Dabrowski, R., \& Lipko, J. (2004). Oxidative stress parameters in bitches with mammary gland tumours. J
Vet Med A, 51(7-8), 336-340. doi:10.1111/j.14390442.2004.00647.x.

Todd, S.E., Thomas, D.G., \& Hendriks, W.H. (2011). Selenium balance in the adult cat in relation to intake of dietary sodium selenite and organically bound selenium. J Anim Physiol Anim Nutr., 96(1), 148-158. doi: 10.1111/j.1439- 0396.2011.01132.x.

Tomsič, K., Nemec, S.A., Nemec, A., Domanjko, P.A.,Vovk, T., \& Seliškar, A. (2018). Influence of sevoflurane or propofolanaesthesia on oxidative stress parameters in dogs with early-stage myxomatous mitral valve degeneration. A preliminary study. ActaVeterinaria-Beograd, 68(1), 32-42. doi: 10.2478/acve2018-0003.

Vajdovich, P., Kriska, T., Mézes, M., Szabó, P.R., Balogh, N., Bánfi, A. et al. (2005). Redox status of dogs with non-hodgkinlymphomas. An ESR study. Cancer Lett., 224(2), 339-346. doi: 10.1016/j.canlet.2004.11.037.

Van Zelst, M., Hesta, M., Gray, K., Staunton, R., Du Laing, G., \& Janssens, G.P. (2016). Biomarkers of selenium status in dogs. BMC Veterinary Research, 12, 15-26. doi: 10.1186/s12917-016-0639-2.

Verk, B., Nemec Svete, A., Salobir, J., Rezar, V., Domanjko Petrič, A. (2017). Markers of oxidative stress in dogs with heart failure. Journal of Veterinary Diagnostic Investigation, 29(5), 636-644. doi: $10.1177 / 1040638717711995$.

Wang, C., Yu, J., Wang, H., Zhang, J., \& Wu, N. (2014). Lipid peroxidation and altered anti-oxidant status in breast adenocarcinoma patients. Drug Res (Stuttg), 64(12), 690-692. doi: 10.1055/s-0034-1372580.

Winter, J.L., Barber, L.G., Freeman, L., Griessmayr, P.C., Milbury, P.E., \& Blumberg, J.B. (2009). Antioxidant status and biomarkers of oxidative stress in dogs with lymphoma. J Vet Intern Med, 23(2), 311-316. doi: 10.1111/j.1939-1676.2009.0273.x. 